\title{
Rancang Bangun Prototype Monitoring Lampu Jalan Secara Otomatis Menggunakan Mikrokontroller ESP32 Dan Api Bot Telegram
}

\author{
Yusril Athallah $^{1}$, Rizqi Agung ${ }^{2}$
}

\begin{abstract}
Public street lighting is one of the most important things because it is related to the security and safety of road users, especially at night which requires good lighting. The lack of lighting on the street, can have a dangerous impact on the community. Along with the development of current technological advances, making changes to the security system and to reduce face-to-face contact in this Covid-19 era. The IoT system is a very flexible system because anything can be controlled via the internet. And also with this IoT system, it is hoped that it will minimize the occurrence of face-to-face dialogue that can result in the transmission of the covid-19 virus. Therefore, an IoT-based system was created that uses the ESP 32 microcontroller as the processing center for checking damaged street lights or Mafunction whose information is sent through the Application Programming Interface (API) to be forwarded to the recipient's BOT Telegram.
\end{abstract}

Keyword: IoT System, Application Programming Interface (API), Telegram, ESP32

Intisari - Penerangan jalan umum merupakan salah satu hal yang paling penting dikarenakan berkaitan dengan keamanan dan keselamatan para pengguna jalan, terutama di malam hari yang membutuhkan penerangan secara baik. Minimnya penerangan di jalan, dapat berdampak berbahaya untuk masyarakat. Seiring dengan berkembangnya kemajuan teknologi saat ini membuat perubahan pada system keamanan dan untuk mengurangi bertatap muka di era covid-19 ini. Sistem IoT menjadi sistem yang sangat fleksibel dikarenakan apapun bisa di control melalui jalur internet. Dan juga dengan adanya sistem IoT ini maka diharapkan dapat meminimalisir terjadinya dialog tatap muka yang dapat mengakibatkan penularan virus covid-19. Oleh karena itu dibuatlah suatu sistem berbasis IoT yang memakai mikrokontroller ESP 32 sebagai pusat pemrosesnya untuk pengecekan lampu jalan yang rusak atau Mafunction yang informasinya dikirim melalui Application Programming Interface (API) untuk diteruskan ke BOT Telegram penerima.

Kata Kunci : Sistem IoT, Application Programming Interface (API), Telegram, ESP32

\footnotetext{
${ }^{1,2}$ Jurusan Teknik Informatika, STMIK Antar Bangsa, Jl. HOS Cokroaminoto, Kawasan Bisnis CBD Ciledug, Blok A5 No 2936, Karang Tengah, Tangerang 15157, tlp: 021-50986099; email: yusath.official@gmail.com, rizqiagung@gmail.com
}

\section{PENDAHULUAN}

Teknologi membuat segalanya yang kita lakukan menjadi lebih mudah.Kita selalu berusaha untuk menciptakan sesuatu yang dapat mempermudah aktivitiasnya sehari-hari, hal inilah yang mendorong perkembangan teknologi yang telah banyak menghasilkan alat untuk mempermudah kegiatan manusia bahkan menggantikan peran manusia dalam suatu fungsi tertentu.

Terbitnya Peraturan Pemerintah tersebut juga dikarenakan adanya peningkatan jumlah kasus penyebaran Covid-19 hingga lintas negara sehingga berdampak pada aspek politik, ekonomi, sosial, budaya, pertahanan dan keamanan, serta kesejahteraan masyarakat Indonesia. Pembatasan Sosial Berskala Besar adalah pembatasan kegiatan tertentu penduduk dalam suatu wilayah yang diduga terinfeksi Covid-19 sedemikian rupa untuk mencegah kemungkinan penyebaran Covid-19. Pembatasan Sosial Berskala Besar (PSBB) diselenggarakan oleh pemerintah daerah yang harus disetujui oleh menteri kesehatan, sehingga dengan persetujuan tersebut pemerintah daerah dapat melakukan Pembatasan Sosial Berskala Besar (PSBB) atau dengan kata lain pembatasan pergerakan orang atau barang dalam satu provinsi atau kabupaten/kota tertentu.[1]

Teknologi memegang peran penting di era modernisasi seperti saat ini, dimana teknologi telah menjadi bagian dalam kehidupan sehari-hari. Sehingga mempermudah untuk berkomunikasi tanpa harus bertatap muka dikarenakan pandemic covid-19 saat ini. Perkembangan teknologi pada saat ini telah merambah ke semua aspek kehidupan sehingga saat ini seolah-olah kita dimanjakan oleh adanya alat-alat yang memberikan kemudahan.

Penerangan jalan umum merupakan salah satu hal yang sangat penting dikarenakan berkaitan dengan keamanan dan keselamatan para pengguna jalan, terutama pada malam hari yang membutuhkan penerangan secara baik. Minimnya penerangan di jalan, dapat berdampak berbahaya untuk masyarakat, contohnya meningkatkan resiko kecelakaan di jalan dan juga meningkatkan angka kriminalitas di jalan.[2]

Untuk itu dibutuhkan suatu perangkat system keamanan yang dapat menjaga keamanan masyarakat. Sehingga yang dapat diharapkan dengan pengaplikasian system keamanan ini maka dapat memberikan rasa 
aman dan nyaman untuk penghuni di perumahanperumahan atau cluster, selain hal tersebut tentunya dengan aplikasi system keamanan ini maka dapat menekan angka kriminalitas yang terjadi di masyarakat. Berdasarkan alasan tersebut, maka penyusun ingin mencoba merancang suatu sistem otomatisasi yang ditempatkan di kompleks perumahan modern atau cluster. Pembuatan alat ini dimaksudkan sebagai pembantu warga perumahan supaya tetap mendapatkan fasilitas penerangan jalan yang dilaksanakan dengan tujuan untuk:

1. Menghindari terjadinya kecelakaan para pengendara motor dan mobil, dan juga menghindari kecelakaan terhadap hewan.

2. Mengurangi resiko adanya tindakan kriminal di wilayah blok FC.

\section{TINJAUAN PUSTAKA}

\section{A. Penghentian penyebaran virus}

Kebijakan pada pemerintah di Negara masingmasing mulai diterapkan, seperti social distancing, karantina, PSBB, sampai lockdown pada daerah tertentu. Hal ini memunculkan pembatasan komunikasi manusia secara interaksi kontak sosial (tatap muka, menyentuh secara fisik) menjadi berkurang, dan terarah pada aktivitas komunikasi dunia maya.[3]

\section{B. Pentingnya penerangan lampu jalan}

Betapa pentingnya suatu proses monitoring lampu penerangan jalan yang efektif, Karena dengan tidak efektifnya proses monitoring lampu penerangan jalan maka akan memperlambat penanganan masalah yang akhirnya juga akan mengakibatkan kerugian pada masyarakat, yaitu meningkatnya angka kerawanan sosial, baik itu kecelakaan lalu lintas maupun tindakan kriminal.[4]

\section{Arduino IDE}

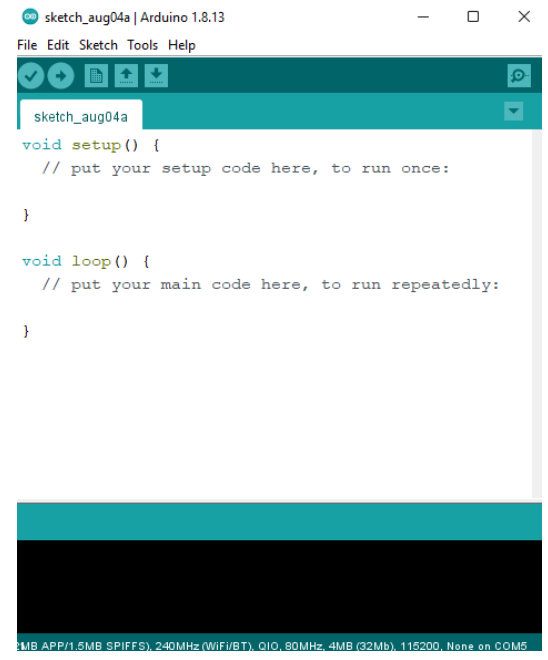

Sumber : Rangkaian Penelitian Gbr 1. Arduino IDE
IDE itu merupakan kependekan dari Integrated Developtment Enviroenment, atau secara bahasa mudahnya merupakan lingkungan terintegrasi yang digunakan untuk melakukan pengembangan. Disebut sebagai lingkungan karena melalui software inilah Arduino dilakukan pemrograman untuk melakukan fungsi-fungsi yang dibenamkan melalui sintaks pemrograman. Arduino menggunakan bahasa pemrograman sendiri yang menyerupai bahasa $\mathrm{C}$. Bahasa pemrograman Arduino (Sketch) sudah dilakukan perubahan untuk memudahkan pemula dalam melakukan pemrograman dari bahasa aslinya. Sebelum dijual ke pasaran, IC mikrokontroler Arduino telah ditanamkan suatu program bernama Bootloader yang berfungsi sebagai penengah antara compiler Arduino dengan mikrokontroler.

Arduino IDE terbuat dari bahasa pemrograman JAVA. Arduino IDE juga dilengkapi dengan library $\mathrm{C} / \mathrm{C}++$ yang biasa disebut dengan Wiring yang membuat operasi input dan output menjadi lebih mudah. Arduino IDE ini dikembangkan dari software Processing yang dirombak menjadi Arduino IDE khusus untuk pemrograman dengan Arduino. Tetapi microcontroller lain bisa menggunakan IDE ini dengan menginstall library khusus untuk microcontroller yang hendak diprogram melalui Arduino IDE.[5]

\section{API}

API atau Application Programming Interface adalah sebuah antar muka yang dapat menghubungkan aplikasi satu dengan aplikasi lainnya. Jadi, API berperan sebagai perantara antar berbagai aplikasi berbeda, baik dalam satu platform yang sama atau lintas platform. Perumpamaan yang bisa digunakan untuk menjelaskan API adalah seorang pelayan di restoran. Tugas pelayan tersebut adalah menghubungkan tamu restoran dengan juru masak. Tamu cukup memesan makanan sesuai daftar menu yang ada dan pelayan memberitahukannya ke juru masak. Nantinya, pelayan akan kembali ke tamu tadi dengan masakan yang sudah siap sesuai pesanan.

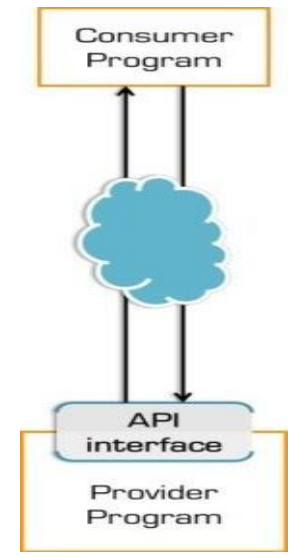

Sumber : https://www.niagahoster.co.id/blog/apiadalah/\#Apa_itu_API Gbr 2. API BOT Telegram 


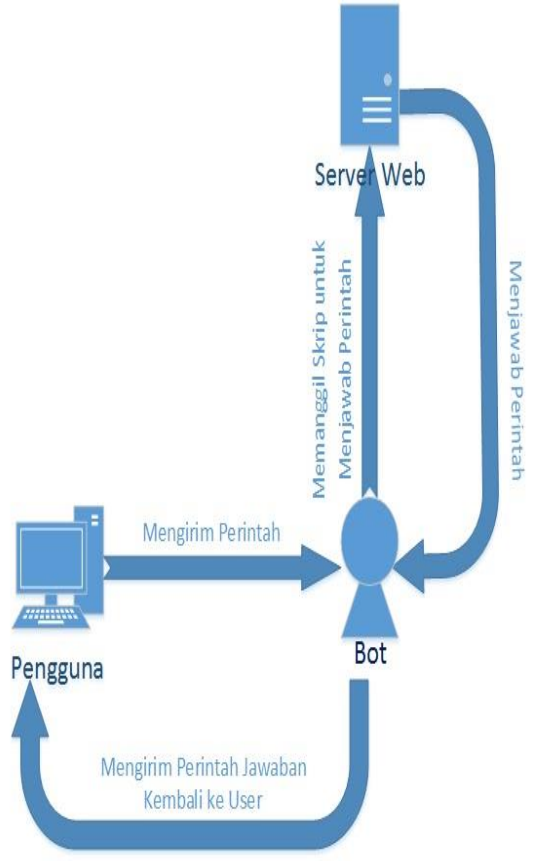

Sumber :

http://awesomerockguy.blogspot.com/2015/10/tutorialsederhana-cara-membuat-bot.htm Gbr 3. Cara kerja BOT

Telegram bot adalah sebuah bot atau robot yang diprogram dengan berbagai perintah untuk menjalankan serangkaian instruksi yang diberikan oleh pengguna." Bot melakukan tugas yang telah ditentukan secara independen dan tanpa keterlibatan pengguna. Istilah bot berasal dari istilah robot.[6]

\section{METODE PENELITIAN}

Metode penelitian yang digunakan dalam penelitian ini adalah sebagai berikut.

\section{A. Analisa Penelitian}

Analisa penelitian data yang dilakukan pada penelitian ini meliputi:

1) Metode Observasi Partisipatoris: Metode observasi partisipatoris bisa dideskripsikan sebagai metode yang dimana peneliti memposisikan dirinya sebagai seorang partisipan seperti orang lain yang sedang di observasi. Dalam memposisikan dirinya sebagai partisipan, peneliti tetap harus menjaga jarak agar unsur objektivitas tetap terjaga. Dalam hal ini peneliti melakukan observasi terhadap lingkungan tempat tinggal dan beberapa cluster di sekitar Blok FC.

2) Metode Literatur: Peneliti mengumpulkan literatur untuk mengumpulkan data dengan cara membaca bukubuku dan situs situs internet yang mendukung dan menunjang dalam pembuatan alat dan penyusunan laporan.
3) Metode Historis: Peneliti mengumpulkan history dan kejadian- kejadin yang pernah terjadi sebelumnya di sekitar perumahan atau cluster untuk mengetahui kemungkinan kemungkinan yang bisa terjadi

4) Metode Perancangan: Peneliti melakukan sebuah proses perancangan, metode yang dibutuhkan untuk memudahkan perancang dalam mengembangkan ide rancangannya. Pola pengembangannya yaitu dengan melakukan beberapa tahapan analisis yang disertai dengan studi literatur untuk mendukung teori yang akan peneliti lakukan.

\section{B. Metode Pengumpulan Data}

Metode pengumpulan data yang dilakukan pada penelitian ini meliputi:

\section{Observasi}

Metode observasi yang dipakai penulis adalah metode observasi partisipatoris. Metode ini dipakai penulis guna melakukan pengamatan langsung di lapangan untuk mendapatkan data yang dibutuhkan untuk menulis laporan.

Peneliti melakukan observasi langsung ke lapangan guna mendapatkan gambaran tetntang permasalahan yang di hadapai yaitu terkait penerangan jalan serta menagalisa kemungkinan -kemungkinan yang terjadi untuk meranacang type sensor atau teknologi yang cocok untuk di terapkan

\section{Wawancara}

Pengumpulan data dapat dilakukan dengan melakukan wawancara kepada para warga khususnya di blok FC ini. Dan untuk tetap mendapatkan saran yang positif, netral dan negatif saya pun melakukan wawancara pada pihak-pihak yang bertanggung jawab dalam menjaga keamanan wilayah blok FC ini, diantaranya ada ketua RW dan ketua RT setempat.

\section{Studi Pusaka}

Peneliti pengumpulan data yang didapat dari buku atau jurnal-jurnal karya ilmiah serta bahan-bahan bacaan lain yang bersangkutan dengan data yang di butuhkan penulis untuk mendukung penulisan Skripsi ini.

\section{PEMBAHASAN DAN HASIL}

Perencanaan dan pembuatan smart home ini terdiri dari beberapa tahap, yaitu : 1) Pembuatan blog diagram, 2) Perencanaan catu daya, 3) Perencanaan input, 4) Perencanaan proses, 5) Perencanaan output, 6) Perencanaan Rangkaian keseluruhan, 7) Perancangan program, dan 8) Pengujian.

\section{A. Blok Diagram}




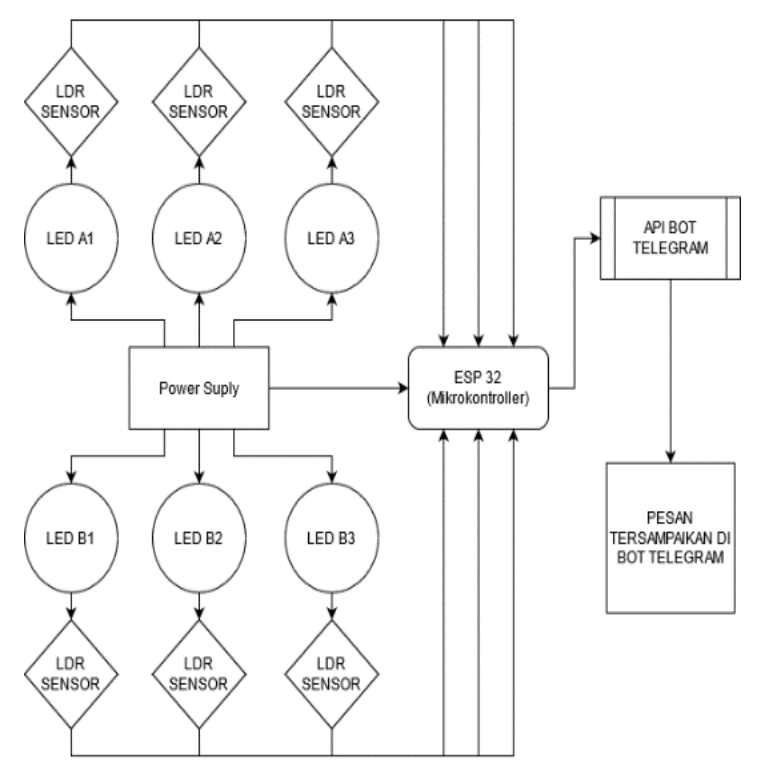

Sumber : Rangkaian Penelitian

Gbr 4. Diagram alat

\section{B. Perencanaan Catu daya}

Ketersediaan catu daya (Power Supply, PS) DC untuk sensor lampu automatic warning system adalah salah satu hal yang penting. Catu daya DC sangat mempengaruhi kinerja keseluruhan dari suatu alat atau modul yang telah dikoneksikan. Catu daya DC yang kurang baik, tentunya akan menghasilkan kinerja yang kurang baik dari alat atau modul yang telah dikoneksikan.

Alat atau modul yang akan dikoneksikan mempunyai konsumsi tegangan sebesar +3.3 VDC. Catu daya DC tetap dengan tegangan keluaran $+3.3 \mathrm{~V}$ mampu mensuplai arus ke beban sampai dengan 1A yang sudah mencukupi kebutuhan daya modul atau alat tersebut.

\section{Perencanaan Input}

1) Perencanaan Sensor: Untuk Sensor yang saya gunakan hanya satu jenis sensor yaitu LDR (Light Dependent Resistor) sensor yang saya pakai ini sensor LDR yang dimana bekerja dengan cara menerima input dari cahaya disekitarnya. Untuk sensor LDR yang dipakai yaitu memakai tipe digital yang dimana memiliki nilai output pasti 1 dan 0 karena sensor digital merupakan sinyal Pulse yang dapat mengalami perubahan yang tiba-tiba.

2)Perencanaan Input Daya: Untuk input daya saya menggunakan Power Supply yang ditenagai oleh sebuah baterai yang mengeluarkan ouput $9 \mathrm{Vdc} 1$ Ampere untuk memberikan daya ke semua komponen yang ada.

2) Perencanaan Proses: Perencanaan ikrokontroller Sebagai tempat utama dalam sebuah pemrosesan dan juga supaya mendukung kinerja alat dan sensor saya dalam membuat alat ini yang dimana saya menggunakan Wi-Fi untuk konektifitas maka mikrokontroller yang saya gunakan adalah ESP-32 DevKit. Saya memilih mikrokontroller ini dikarenakan sudah Built-in dengan Wi-FI dan Bluetooth yang menjadikan komponen yang saya gunakan dan budget yang diperlukan menjadi lebih murah dan hemat, dikarenakan saya tidak perlu lagi untuk membeli sebuah module Wi-Fi eksternal.

3) Perencanaan Output: Perencanaan Pesan warning melalui Bot Telegram Untuk output yang maksimal dan bisa di akses dari mana saja maka saya menggunakan Bot Telegram. Yaitu dengan cara memanfaatkan API yang diberikan oleh sebuah bot lalu dintegrasikan langsung ke program mikrokontroller esp-32 devkit supaya terhubung.

4) Rangkaian Keseluruhan

Skematik Diagram

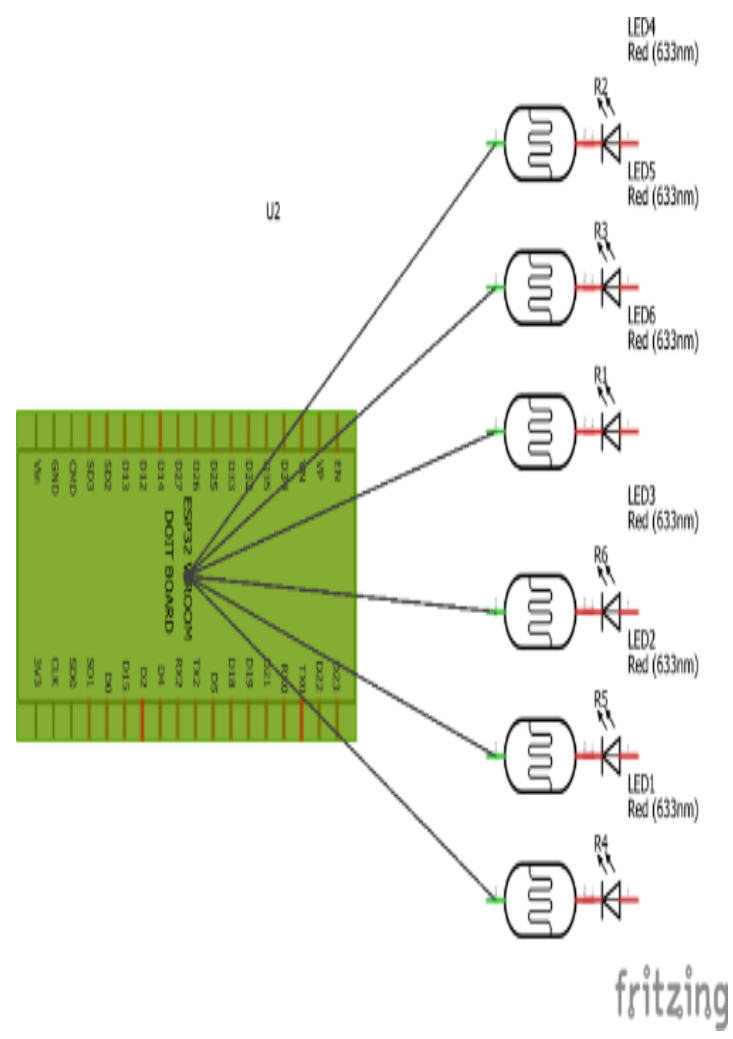

Sumber : Rangkaian Penelitian

Gbr 5. Skematik Diagram 
5) Perencanaan Program

1. Flowchart Program

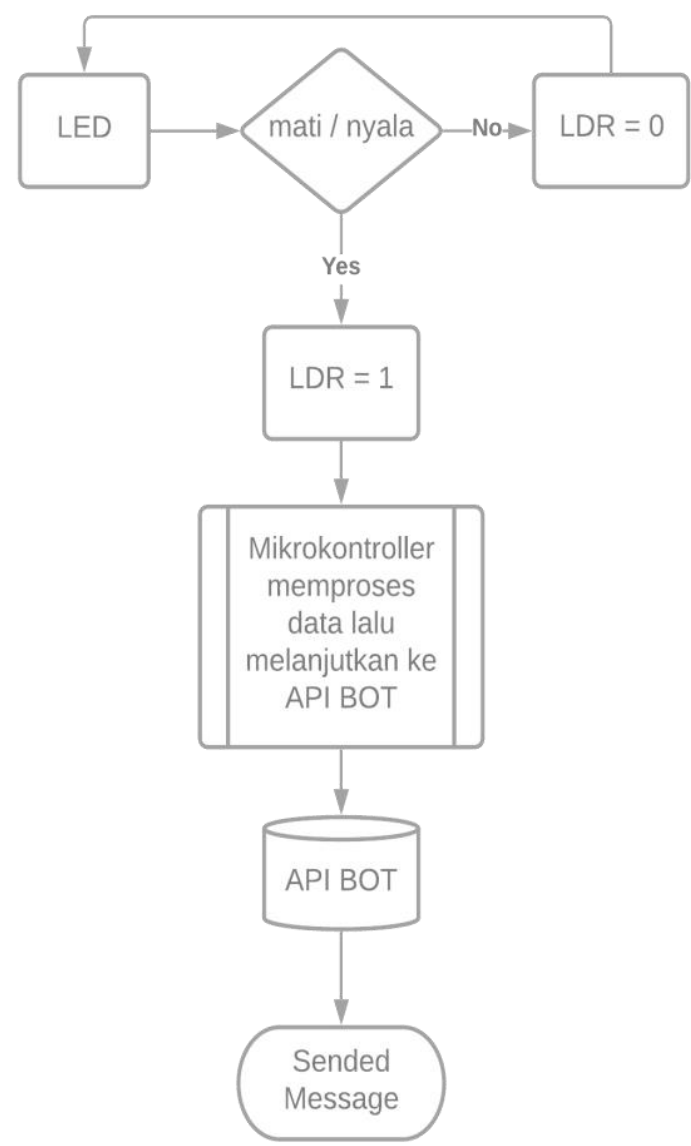

Sumber : Rangkaian Penlitian Gbr 6. Flowchart Program

\section{Kontruksi Sistem (Coding)}

\#include $<\mathrm{WiFi} . \mathrm{h}>$

\#include $<$ WiFiClientSecure.h $>$

\#include <UniversalTelegramBot.h $>$

\#include <ArduinoJson.h>

// Replace with your network credentials

const char* ssid = "Rakhmat";

const char* password = "wifirakhmat123";

// Initialize Telegram BOT

\#define BOTtoken "1836141078:AAGpUQW4JH-

xgZ5545kLCr4G49o00MkIeBo" // your Bot Token (Get from Botfather)

// Use@ @yidbot to find out the chat ID of an individual or a group

// Also note that you need to click "start" on a bot before it can

// message you

\#define CHAT_ID "574967010"

unsigned long previousMillis $=0$;

unsigned long interval $=30000$; const unsigned long BOT_MTBS = 1000; // mean time between scan messages

WiFiClientSecure client;

UniversalTelegramBot bot(BOTtoken, client);

unsigned long bot_lasttime; // last time messages' scan has been done

// GANG A

const int $\operatorname{ldr} \mathrm{A} 1=25$; // ldr sens

const int ldrA2 = 26; // ldr sens

const int ldrA $3=27$; // ldr sens

// GANG B

const int $\operatorname{ldrB} 1=18 ; / /$ ldr sens

const int $\operatorname{ldrB} 2=19 ; / /$ ldr sens

const int ldrB3 = 21; // ldr sens

$\operatorname{void}(*$ restart $)($ void $)=0$;

void setup() \{

Serial.begin(115200);

Serial.println();

// PIR Motion Sensor mode INPUT_PULLUP pinMode(ldrA1, INPUT); //sensor ldr 1 input pinMode(ldrA2, INPUT); //sensor ldr 2 input pinMode(ldrA3, INPUT);

pinMode(ldrB1, INPUT);

pinMode(ldrB2, INPUT);

pinMode(ldrB3, INPUT);

Serial.print("Connecting to Wifi SSID ");

WiFi.begin(ssid, password);

client.setCACert(TELEGRAM_CERTIFICATE_RO OT);

while (WiFi.status() != WL_CONNECTED) \{

Serial.print(".");

delay (500);

\}

\}

boolean cahaya $=$ true;

void handleNewMessages(int numNewMessages)

\{

Serial.print("handleNewMessages ");

Serial.println(numNewMessages);

for (int $\mathrm{i}=0$; i $<$ numNewMessages; $\mathrm{i}++$ )

\{

String chat_id $=$ bot.messages[i].chat_id;

String text $=$ bot.messages $[\mathrm{i}]$.text;

String from_name = bot.messages[i].from_name;

if (from_name $==$ "")

from_name = "Guest";

if $($ text $==$ "/done") 


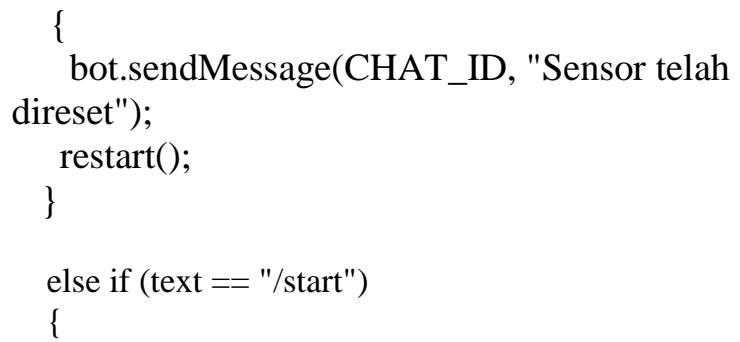

Serial.print("Sensor value:");

Serial.println(sensorData1);

Serial.println(sensorData2);

Serial.println(sensorData3);

Serial.println(sensorData4);

Serial.println(sensorData5);

Serial.println(sensorData6);

if (millis() - bot_lasttime > BOT_MTBS)

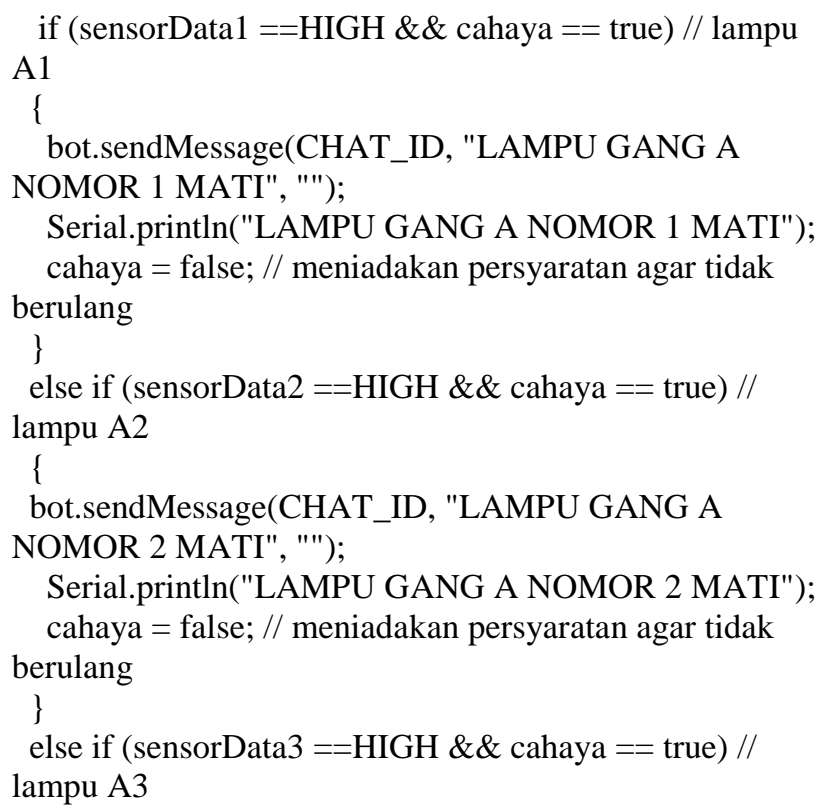

\section{bot.sendMessage(CHAT_ID, "LAMPU GANG A \\ NOMOR 3 MATI", "");}

Serial.println("LAMPU GANG A NOMOR 3 MATI"); cahaya = false; // meniadakan persyaratan agar tidak berulang

\}

else if (sensorData4 ==HIGH \& \& cahaya == true) //

lampu B1

\{

bot.sendMessage(CHAT_ID, "LAMPU GANG B

NOMOR 1 MATI", "");

Serial.println("LAMPU GANG B NOMOR 1 MATI");

cahaya = false; // meniadakan persyaratan agar tidak berulang

\}

else if ( sensorData5 ==HIGH \& \& cahaya == true) $/ /$ lampu B2

\{

bot.sendMessage(CHAT_ID, "LAMPU GANG B

NOMOR 2 MATI", "");

Serial.println("LAMPU GANG B NOMOR 2 MATI");

cahaya = false; // meniadakan persyaratan agar tidak berulang

\}

else if $($ sensorData6 $==$ HIGH $\& \&$ cahaya $==$ true $) / /$ lampu B3

\{

bot.sendMessage(CHAT_ID, "LAMPU GANG B

NOMOR 3 MATI", "");

Serial.println("LAMPU GANG B NOMOR 3 MATI");

cahaya $=$ false; $/ /$ meniadakan persyaratan agar tidak berulang

\}

6) Pengujian

1. Tujuan Pengujian

Tujuan dari pengujian alat rancang bangun prototipe monitoring lampu jalan secara otomatis menggunakan mikrokontroller ESP32 dan Api Bot Telegram adalah sebagai berikut:

a. Untuk mengetahui sensor LDR bekerja dengan baik atau tidak dalam menerima cahaya dari lampu.

b. Untuk mengetahui sensor LDR dapat mengirimkan data dengan baik yang telah diperoleh.

c. Untuk mengetahui apakah microcontroller dapat terhubung ke internet.

d. Untuk mengetahui apakah pesan dari ldr lalu diproses oleh mikrokontroller lalu dikirimkan ke Api Bot telegram berhasil atau gagal.

e. Untuk mengetahui apakah alat ini berkontribusi dalam meningkatkan keamanan dan serta mengurangi kecelakaan dikarenakan malfunction lampu penerang jalan umum.

\section{Langkah-langkah Pengujian}

Pengujian adalah yang paling umum digunakan dalam suatu penelitian, hal ini penulis gunakan untuk mengetahui 
apakah alat bekerja dengan normal ataukah masih terdapat eror. Berikut.Hasil Pengujian alat.

\section{HASIL PENGUJIAN}

\section{A. Pengujian Input}

Hasil dari pengujian imput didapatkan kesimpulan bahwa ESP-32 Devkit Module berjalan dengan baik dengan mengirimkan nilai true dan false pada GPio dengan cepat dan Ketika dinyalakan pendeteksi lampu yang rusak atau Malfunction dapat berjalan baik dan juga data dari sensor cepat disalurkan ke mikrokontroller.

TABEL I

\begin{tabular}{|c|c|c|}
\hline Pengujian & Fungsi & Output \\
\hline Cek & User dapat & Perangkat \\
Koneksi & mengopersaika & merespon \\
& n perangkat jika & dan \\
& bot Telegram & membalas \\
& dan & pesan. \\
& mikrokontroler & Menunjuka \\
& telah terhubung & n perangkat \\
& & telah \\
& & terhubung \\
\hline LED dan & Sensor untuk & Mengirim \\
LDR & melihat lampu & pesan ke \\
& yang error dan & bot jika ada \\
& rusak & lampu yang \\
& & rusak dan \\
& & error \\
\hline Memasuka & Respon untuk & Perangkat \\
n perintah & mereset alat & merespon \\
"Reset" & setelah lampu & dan sensor \\
& selesai & mendeteksi \\
& diperbaiki & Kembali \\
& & lampu- \\
& & lampu \\
\hline & &
\end{tabular}

\section{TAHAP PENGUJIAN}

\section{B. Pengujian Proses}

Hasil dari pengujian proses didapatkan kesimpulan bahwa ESP-32 Devkit berjalan dengan baik pada module GPio yang berfungsi sebagai penerus data yang diterima dari sensor LDR. Selama pengujian tidak terjadi masalah terhadap kinerja ESP-32. Akan tetapi pengujian terjadi masalah terhadap ESP32 ketika merestart melalui perintah dari Api Bot yang menjadikan wifi tidak bisa membaca sinyal ssid wifi sekitar dan harus mematikan alat secara manual sehingga proses restart ESP-32 ini akan sedikit mengganggu kenyamanan dalam menggunakan perintah di API BOT.

\section{Pengujian Output}

Hasil dari pengujian output yaitu pesan dengan cepat dapat tersampaikan melalui API Bot telegram sesuai dengan data yang diterima dari sensor LDR. Tidak ada masalah selama output berlangsung.

\section{Analisa Hasil}

Hasil dari prototype yang pertama ialah bahwa mendapatkan info data ldr dari lampu dapat berjalan dengan baik, dan juga data dapat dikirim melalui mikrokontroller esp-32 untuk serta dilanjutkan ke Api bot telegram dapat berjalan dengan maksimal.

Hasil dari prototype yang kedua ialah didapatkan kesimpulan bahwa alat ini secara keseluruhan dapat berjalan dengan baik. Akan tetapi terdapat error pada koneksi ke wifi ketika alat direstart melalui perintah bot. Untuk error tidak bisa konek ke wifi ini dikarenakan alat ini merestart dan melewati ssid dan password yg telah di atur.

\section{KESIMPULAN DAN SARAN}

Dari hasil penelitian skripsi mengenai system analisis sentiment, penulis akan menyimpulkan hasil penelitian yang ada dalam penulisan skripsi ini adalah sebagai berikut:

\section{A. Kesimpulan}

Berdasarkan hasil analisis terhadap masalah dan alat yang dikembangkan, maka penulis dapat mengambil beberapa kesimpulan sebagai berikut :

1. Dari hasil alat prototipe yang telah di buat, alat ini akan mengirim status kondisi pada lampu penerangan jalan umum. Dengan tingkat keberhasilan $100 \%$.

2. Alat ini dapat dengan mudah terkoneksi dimanapun selama ada Wi-Fi. Dimana kita tau dijaman serba canggih ini internet adalah hal yang sangat sulit dipisahkan dari kehidupan sehari-hari.

3. Alat ini secara otomatis mengirim data ke API bot Telegram melalui internet lalu dari API data tersebut diteruskan ke BOT Telegram untuk memberitau jika ada kerusakan lampu pada malam hari.

4. Dari hasil penerapan alat ini bisa mengurangi adanya kontak langsung untuk memberikan suatu info ke pihak penanggung jawab seperti RT jika terjadi kerusakan lampu.

5. Dari hasil penerapan alat ini bisa mempercepat pergantian atau perbaikan lampu-lampu yang rusak atau malfunction di perumahan.

6. Alat ini dapat mampu mengurangi adanya tindak kejahatan yang memanfaatkan adanya titik Blindspot ketika ada lampu yang rusak atau mati.

B. Saran

Dari pembahasan dan penjelasan diatas maka penulis ingin memberikan beberapa saran sebagai alternative pemikiran yang dapat dijadikan masukan yang nantinya akan sangat berguna untuk mendukung kelancaran terlaksanannya alat sensor ini yaitu mengupgrade alat ini dengan system keamanan yang lebih ketat serta pengontrolan jarak jauh yang lebih effisien dengan bantuan teknologi Internet Of Thinks (IOT).

Untuk pengembangan kedepannya pola sistem seperti ini bisa digunakan luas seperti untuk On/Off lampu rumah dari jarak jauh, buka tutup pagar otomatis dari jarak jauh, dan sistem buka kunci otomatis dari jarak jauh. 


\section{REFERENSI}

[1] Hasrul, M. 2020. Aspek Hukum Pemberlakuan Pembatasan Sosial Berskala Besar (PSBB) Dalam Rangka Penanganan Corona Virus Disease 2019 (Covid-19). Jurnal Legislatif, 385-398.Diambil dari: https://journal.unhas.ac.id/index.php/jhl/article/view/10477 (22 Juni, 2021)

[2] Saputra, A., Setiawan, J., Carmanto, A., Sanofel, F., Irwansyah, N., Mubarok, H., ... \& Abidin, J. 2021. PROGRAM PENGADAAN DAN PEMASANGAN LAMPU PENERANGAN JALAN UMUM DI PONDOK SUKATANI PERMAI, KELURAHAN SUKATANI, KECAMATAN RAJEG, KABUPATEN TANGERANG. Jurnal Pengabdian Kepada Masyarakat (JPKM)-Aphelion, 1(2), 144-154. Diambil dari: http://www.openjournal.unpam.ac.id/index.php/JPKA/article/view/96 $\underline{44}$ (16 Juli 2021)

[3] Dani, J. A., \& Mediantara, Y. 2020. Covid-19 dan perubahan komunikasi sosial. Persepsi: Communication Journal, 3(1), 94-102. Diambil dari: http://jurnal.umsu.ac.id/index.php/PERSEPSI/article/view/4510 (18 Juli 2021)

[4] Norazizi, N., \& Adam, A. 2019. SISTEM MONITORING LAMPU PENERANGAN JALAN UMUM BERBASIS SMS. Jurnal Ilmiah Flash, 5(1), 23-28. Diambil dari: http://222.124.191.188/index.php/flash/article/view/629 $\quad(19$ Juli 2021)

[5] Sinauarduino. 2016. Mengenal Arduino Software (IDE). Diambil dari: https://jurnal.stairakhaamuntai.ac.id/files/journals/1/articles/109/subm ission/original/109-219-1-SM.html (6 Agustus 2021)

[6] Ariskisaputri. 2019. Pengertian, fungsi dan cara menggunakan bot telegram. Diambil dari: https://www.bukugue.com/apa-itu-bottelegram/ (6 Agustus 2021)

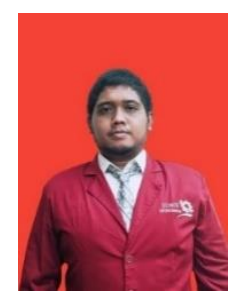

Yusril Athallah Muhammad Yazid. Lahir pada tanggal 28 Desember 1998. Tahun 2021 lulus dari Program Strata Satu (S1) Program Studi Teknik Informatika di STMIK Antar Bangsa.

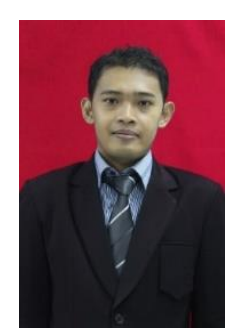

Rizqi Agung Permana, M.Kom. Tahun 2010 lulus dari Program Diploma (D3) Komputer Akuntansi AMIK BSI. Tahun 2012 lulus dari Program Strata Satu (S1) Sistem Informasi STMIK Nusa Mandiri. Tahun 2015 lulus dari Program Magister (S2) Ilmu Komputer STMIK Nusa Mandiri. Dosen di STMIK Antar Bangsa. Aktif melakukan penelitian di bidang data mining dan text mining. 